\title{
Advances in Alkaline water electrolyzers: A review
}

\author{
Martin David ${ }^{\mathrm{a}, \mathrm{b}, \mathrm{c}, *}$, Carlos Ocampo-Martinez ${ }^{\mathrm{c}}$, Ricardo Sanchez-Peña ${ }^{\mathrm{a}, \mathrm{b}}$ \\ ${ }^{a}$ Instituto Tecnológico Buenos Aires, Ciudad Autónoma de Buenos Aires, Argentina \\ ${ }^{b}$ Consejo Nacional de Investigaciones Científicas y Técnicas (CONICET), Ciudad Autónoma de \\ Buenos Aires, Argentina \\ ${ }^{c}$ Automatic Control Department, Universitat Politècnica de Catalunya, Institut de Robòtica $i$ \\ Informàtica Industrial (CSIC-UPC), Barcelona, España
}

\begin{abstract}
The renewed concern for the care of the environment has led to lower emissions of greenhouse gases without sacrificing modern comforts. Widespread proposal focuses on energy produced from renewable sources and its subsequent storage and transportation based on hydrogen. Currently, this gas applies to the chemical industry and its production is based on fossil fuels. The introduction of this energy vector requires the development of environmental-friendly methods for obtaining it. In this paper, existing techniques are just presented and the main focus is made on electrolysis, a mature procedure. In turn, some developed proposals as previous steps to the hydrogen economy are presented. Finally, some lines of research to improve alkaline electrolysis technology are commented.

Keywords:

Hydrogen economy, hydrogen production, electrolysis
\end{abstract}

\footnotetext{
${ }^{*}$ Corresponding author

Email address: mdavideitba.edu.ar (Martin David)
} 


\section{Introduction}

The world economy is constantly expanding. There are two influencing factors related to that expansion: the population growth and progress in personal comfort. Both factors affect the current fossil economy by increasing consumption and generating greater amount of greenhouse gases $(\mathrm{GHG})$. The International Energy Agency (IEA) indicates a world consumption in 2015 of 9.383 Mtoe $\left(1.1 \times 10^{5}\right.$ TWh). This amount represents an increase of $18,23 \%$ and $99.64 \%$ over the past ten (2005) and fourty (1975) years, respectively. Besides, $\mathrm{CO}_{2}$ emissions in 2015 were 32.294 MTon, compared to 15.484 MTon in 1975 (109\% increment) [1]. This situation is widely accepted as critical, hence worldwide environmental impact studies and environmental protection policies are generated. Moreover, the fact that fossil fuels are neither renewable nor evenly distributed across the globe leads to geopolitical conflicts and unequal situations.

Around the world, proposed solutions focus on the production of renewable energy. However, the share of renewable energies has not grown significantly (from $12.7 \%$ in 1975 to $13.5 \%$ in 2015). Besides costs issues, the global experience indicates that advances are needed to solve technical problems related to energy fluctuations produced in renewable sources. To achieve high integration of renewable energy, it is necessary to have the ability to accumulate the excess of energy to be consumed at a time when consumption exceeds production. Figure 1 shows the variety of available technologies for energy storage. While some technologies such as supercapacitors or flywheels are used to store a reduced amount of power (up to 10MW) for a short time (up to an hour) and redeliver it quickly,

for the case raised, it is necessary to use other technologies such as Compressed Air Energy Storage (CAES), Pumped Hydro Energy Storage (PHES) or hydrogen. 


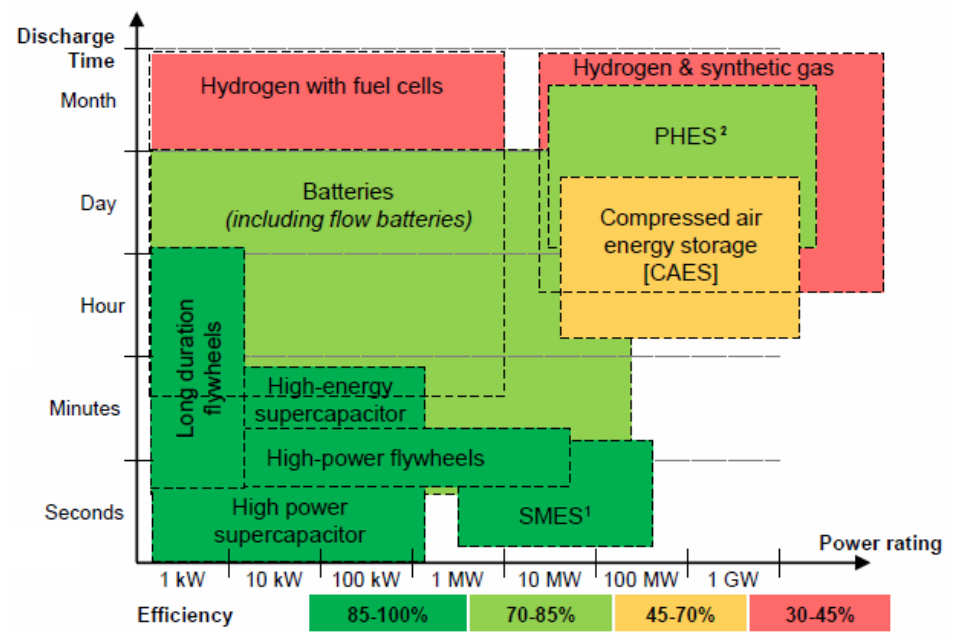

Figure 1: Current energy storage methods (taken from [2]). ${ }^{1}$ SMES: Superconducting Magnetic Energy Storage, ${ }^{2}$ PHES: Pumped Hydro Energy Storage

So far, the most common way to store large amounts of energy is PHES. The biggest disadvantage of this technology is related to its requirements on specific geographical features for installation and political conditions. It is here that among the methods of energy storage, hydrogen production currently takes relevance for its energy density, high energy capacity and transportability $[2,3]$.

Moreover, in the same direction, there is the concern about pollution in the transportation sector. Along with the development of electric vehicles, the hydrogen appears as an interesting energy vector. Both technologies, electric and $\mathrm{H}_{2}$-based vehicles, share the benefit of eliminating urban pollution and, depending on the original source, reducing or eliminating pollution in the whole process [4]. The union of these two sectors, electricity and transport, generates what is disclosed as hydrogen economy. The hydrogen economy is stated as an integral solution for the problem of producing, storing and supplying energy including all 
final uses while succeeding in GHG mitigation.

The industrial use of hydrogen dates from almost a century ago with a wide consumption in the chemical and oil industries (89\% of consumption share) [5]. However, progress must be achieved in various issues in order to accomplish competitiveness of these technologies and develop this economic concept. Issues such as the efficiency and cost of production, storage and transport, are concepts that several companies, research centers and governments are developing.

Several reviews can be found that present the different technologies related to the use of hydrogen. Abdalla et al [6] published a review of hydrogen technologies making a detailed explanation and comparison of current storage methods. Zhang et al [7] present a brief and well-organized compendium of production, storage and electricity generation technologies. Dutta [8] summarizes development models for the hydrogen economy in various countries along with an explanation of hydrogen production, storage and utilization. Mazloomi and Gomes [9] discuss the economic aspects of centralized and distributed production. In addition, they present the risks inherent in the production, storage and distribution stages, proposing possible risk-reduction techniques.

At the same time, there are studies such as [10] that detail the steps to be followed in order to reach a mature hydrogen economy. Among those steps there are the Power-to-Gas $[11,12]$, the use of fossil hydrogen to power vehicles $[13,14$, $15,16]$ and the integration of electrolyzers with renewable energies in microgrids $[17,18]$. All these developments bring hydrogen technologies taking into account the necessary economic issues in order for it to be sustainable over time. To do this, it will be necessary that companies, governments and research centers cooperate together in this direction [13]. 
This paper provides an overview of the hydrogen production technologies, specifically emphasizing production from alkaline electrolysis. Mueller-Langer et al [19] in their techno-economic assessment assure that natural gas steam reforming, coal and biomass gasification and water electrolysis will play a significant role in the short and medium term. Besides, electrolysis occupies until today a dominant position as it is the only technology that can use directly the power surplus from renewable and fluctuating energies like wind mills or solar panels [7] so it has a concrete perspective on the use of this type of energy as the axis of the hydrogen economy. Among $\mathrm{CO}_{2}$-neutral $\mathrm{H}_{2}$ production, electrolysis highlight because it produces high purity hydrogen and it has an infrastructure already developed being a well-established technology [20, 21]. In the same direction, alkaline electrolysis is a mature and reliable technology which stands out from other types of electrolysis based on cost and simplicity [22].

The remainder of this paper is organized as follows. In Section 2, hydrogen production technologies are compared according to efficiency, costs and environmental consequences. After that, in Section 3, water electrolysis, as the most certain solution for ecofriendly hydrogen production, is described. Then, in Section 4, necessary developments in alkaline electrolyzers in the short and long term are displayed. Finally, conclusions in Section 6 reinforce the necessity to advance research to achieve the reduction of pollution through the hydrogen economy.

Figure 2 shows the different methods of hydrogen production presented in Section 2. It highlights the approach outlined in this paper, explaining its organization. 


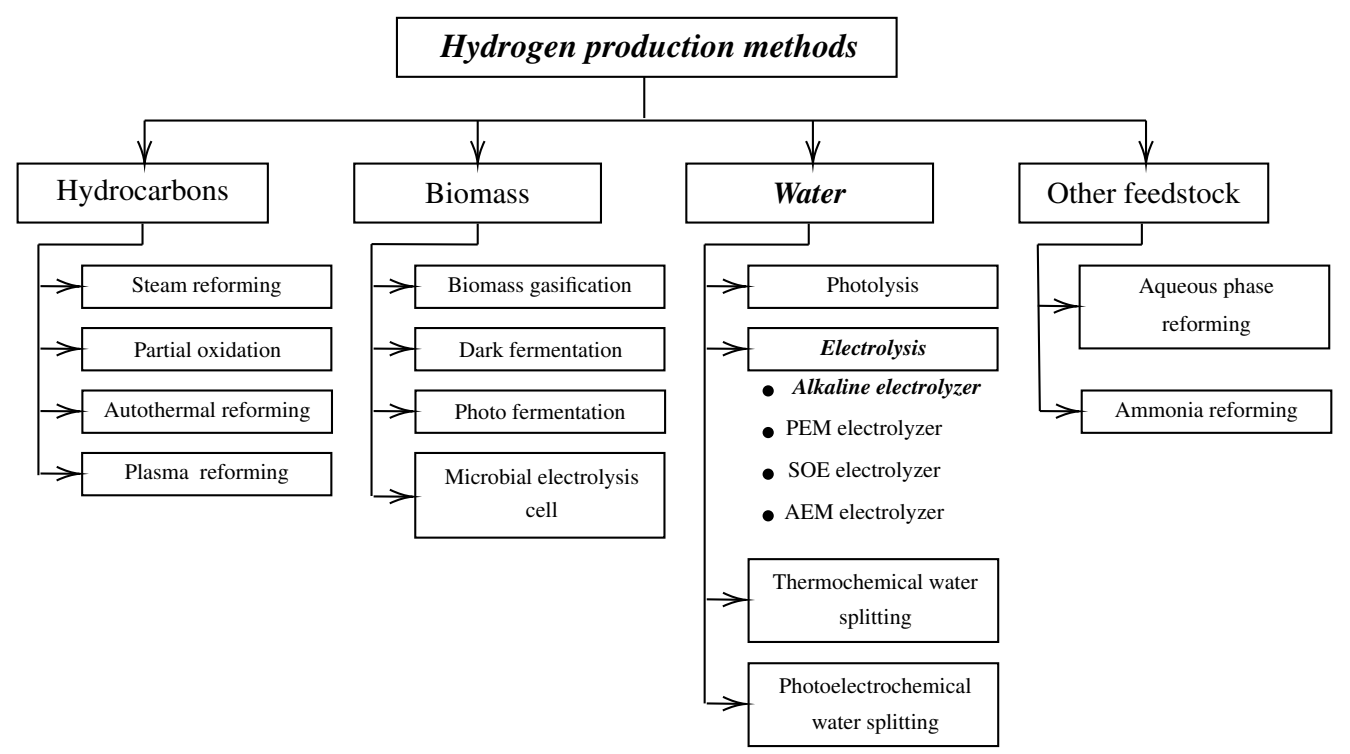

Figure 2: Taxonomy of hydrogen production with emphasis in this paper's objective (in boldface)

\section{Hydrogen production methods}

There are several methods of hydrogen production with different stages of development. Currently, its production is mainly based on the reforming of fossil fuels $(78 \%)$ and coal gasification (18\%). From the pending $4 \%$ of alternate resources, the main technology is the electrolysis of water as a byproduct from chlor-alkali process $[23,24]$. Despite the current use of hydrogen produced by the last process, this technology will not be considered in the analysis because in the long term and taking into account the amount of hydrogen necessary, it would not be sustainable due to the chlorine produced at the same time.

In addition to the named technologies, in Table 1 it can be seen the selection offered by Holladay et al. [25] covering industrial methods and those which are being developed.

Some of the parameters used to compare different methods of hydrogen pro- 
duction are efficiency, cost and environmental consequences. Efficiency, overall, compares the energy provided by the one obtained as the Lower Heating Value (LHV) of $\mathrm{H}_{2}$ produced, whose ranges are listed in Table 1.

Moreover, the economic cost has the difficulty of analyzing mature technologies such as the steam methane reforming (SMR) with newly developed methods on a laboratory scale as photolysis. In turn, the technologies that rely on fossil fuels have different costs in case carbon capture and storage (CCS) approaches are considered or not. For instance, Parthasarathy and Narayanan [38] present SMR and coal gasification as the cheapest options $\left(0.75 \mathrm{U} \$ \mathrm{Skg}^{-1}\right.$ and $0.92 \mathrm{U} \$ \mathrm{Skg}^{-1}$ of $\mathrm{H}_{2}$ produced, both without $\mathrm{CO}_{2}$ capture) while electrolysis, considering the production of electricity with nuclear energy, costs between $2.56 \mathrm{U} \$ S k g^{-1}$ and 2.97 $\mathrm{U} \$ \mathrm{Skg}^{-1}$.

Besides, Hosseini et al [39] present a cost comparison between some production methods as can be seen in Table 2. Production from fossil fuels was shown to be cheaper, even if CCS were required. Levene et al [40] consider that electricity costs have a great influence on the price of hydrogen produced by electrolysis, so it is concluded that the cost of electricity must be four times lower than the current price to have a competitive solution using solar and wind energy.

Concerning the environmental consequences, there are two commonly used rates. Bhandari et al indicate that most of the studies analyzed are concentrated in the Global Warming Potential (GWP) and some in the Acidification Potential (AP) [42]. These potentials measure the equivalent mass of $\mathrm{CO}_{2}$ and $\mathrm{SO}_{2}$ emitted per kilogram of $\mathrm{H}_{2}$ generated, respectively. Figures 3 and 4 show the comparison of these rates for electrolysis from various renewable energy sources along with other methods of obtaining hydrogen. Marks above the bars in the graph high- 
Table 1: Summary of methods for obtaining $\mathrm{H}_{2}$ (adapted from [25])

\begin{tabular}{|c|c|c|c|c|c|}
\hline Technology & Energy source & Feedstock & Efficiency & Maturity & Reference \\
\hline Steam reforming & Thermal & Hydrocarbons & $70-85 \%^{a}$ & Commercial & {$[26]$} \\
\hline Partial oxidation & Thermal & Hydrocarbons & $60-75 \%{ }^{a}$ & Commercial & {$[26]$} \\
\hline Autothermal reforming & Thermal & Hydrocarbons & $60-75 \%{ }^{a}$ & Near term & {$[26]$} \\
\hline Plasma reforming & Electric & Hydrocarbons & $9-85 \%^{b}$ & Long term & {$[27]$} \\
\hline Aqueous phase reforming & Thermal & Carbohydrates & $35-55 \%{ }^{a}$ & Mid term & {$[28]$} \\
\hline Ammonia reforming & Thermal & Ammonia & $\mathrm{NA}^{c}$ & Near term & - \\
\hline Biomass gasification & Thermal & Biomass & $35-50 \%{ }^{a}$ & Commercial & {$[29,30,31]$} \\
\hline Photolysis & Solar & Water & $0.5 \%{ }^{d}$ & Long term & {$[32]$} \\
\hline Dark fermentation & Biochemical & Biomass & $60-80 \%^{e}$ & Long term & {$[29,33]$} \\
\hline Photo fermentation & Solar & Biomass & $0.1 \%{ }^{f}$ & Long term & {$[29,30]$} \\
\hline Microbial electrolysis cell & Electric & Biomass & $78 \%^{g}$ & Long term & {$[34]$} \\
\hline Alkaline electrolyzer & Electric & Water & $50-60 \%{ }^{h}$ & Commercial & {$[30,35]$} \\
\hline PEM electrolyzer & Electric & Water & $55-70 \%{ }^{h}$ & Commercial & {$[30,35,36]$} \\
\hline Solid oxide electrolysis cell & Electric+Thermal & Water & $40-60 \%^{i}$ & Mid term & {$[31]$} \\
\hline Thermochemical water splitting & Thermal & Water & $\mathrm{NA}^{c}$ & Long term & - \\
\hline Photoelectrochemical water splitting & Solar & Water & $12.4 \%^{d}$ & Long term & {$[35,37]$} \\
\hline
\end{tabular}

${ }^{a}$ Thermal efficiency, based on the Higher Heating Values (HHV)

${ }^{b}$ Based on efficiency equation from [27]

${ }^{c}$ Not available

${ }^{d}$ Solar to hydrogen via water splitting and does not include hydrogen purification

${ }^{e}$ Percent of $4 \mathrm{~mol} \mathrm{H}_{2}$ per mole glucose theoretical maximum

${ }^{f}$ Solar to hydrogen via organic materials and does not include hydrogen purification

${ }^{g}$ Overall energy efficiency including the applied voltage and energy in the substrate. It does not include hydrogen purification

${ }^{h}$ Lower heating value of hydrogen produced divided by the electrical energy to the electrolysis cell

${ }^{i} \mathrm{High}-\mathrm{temperature}$ electrolysis efficiency is dependent on the temperature the electrolyzer operates at and the efficiency of the thermal energy source. If thermal energy input is ignored, efficiencies up to $90 \%$ have been reported [31]. 
Table 2: Cost of hydrogen production methods (from [39])

\begin{tabular}{|l|c|}
\hline Process & Cost of $\mathrm{H}_{2}\left(\mathrm{USDkg}^{-1}\right)$ \\
\hline \hline Natural gas reforming & 1.03 \\
\hline Natural gas reforming + CCS & 1.22 \\
\hline Natural gas reforming + PSA + CCS & \\
\hline Coal gasification & 1.56 \\
\hline Coal gasification + CCS & 0.96 \\
\hline Wind electrolysis & \\
\hline Biomass gasification & 1.03 \\
\hline Biomass pyrolisis & 6.64 \\
\hline Nuclear thermal splitting of water & 4.63 \\
\hline Gasoline (for comparison purposes) & 3.80 \\
\hline
\end{tabular}

${ }^{a}$ Current central $\mathrm{H}_{2}$ production from Natural Gas with Pressure Swing Adsortion (PSA) used for $\mathrm{H}_{2}$ purification up to $99.6 \%$ [41]

${ }^{b}$ Electrolysis using electricity generated by wind turbines 
lights the different GWP values extracted by Bhandari et al from their sources [42]. It must be emphasized that these studies are based on Life Cycle Assessment (LCA), which comprises the construction, operation and end of cycle of each technology. It can be seen that electrolysis together with renewable sources produces less pollution than widely used technologies, even in cases of considering CCS. Although thermal decomposition has better results, it still needs to be developed. Besides, biomass gasification is slightly more polluting than electrolysis but it is a technology that also receives interest today.

Based on the previous study, Dincer and Acar [43] present an analysis comparing various technologies based on sustainability and costs. It is necessary to clarify that for the calculation of the environmental impact of electrolysis, these authors took the average value of all sources of electricity, including the grid. Therefore, due to the fact that the electricity network has higher polluting emissions, the GWP value of electrolysis appears as a non ecofriendly method. This is not the case when electrolysis is combined with renewable sources, as will be considered in this work.

While the electrolysis was the first commercial method of obtaining hydrogen [42], other methods such as SMR have taken its place and are today the processes used at industrial level because of their better efficiency and costs. However, facing the new optical of environment care and GHG emissions mitigation, electrolysis takes back relevance and the research is aimed at improving those two aspects.

Moreover, there are various methods of producing hydrogen which are ecofriendly and competitive. Currently, there is a strong research on the use of biomass, which is accepted as the substitute for the use of fossil resources [39]. How- 


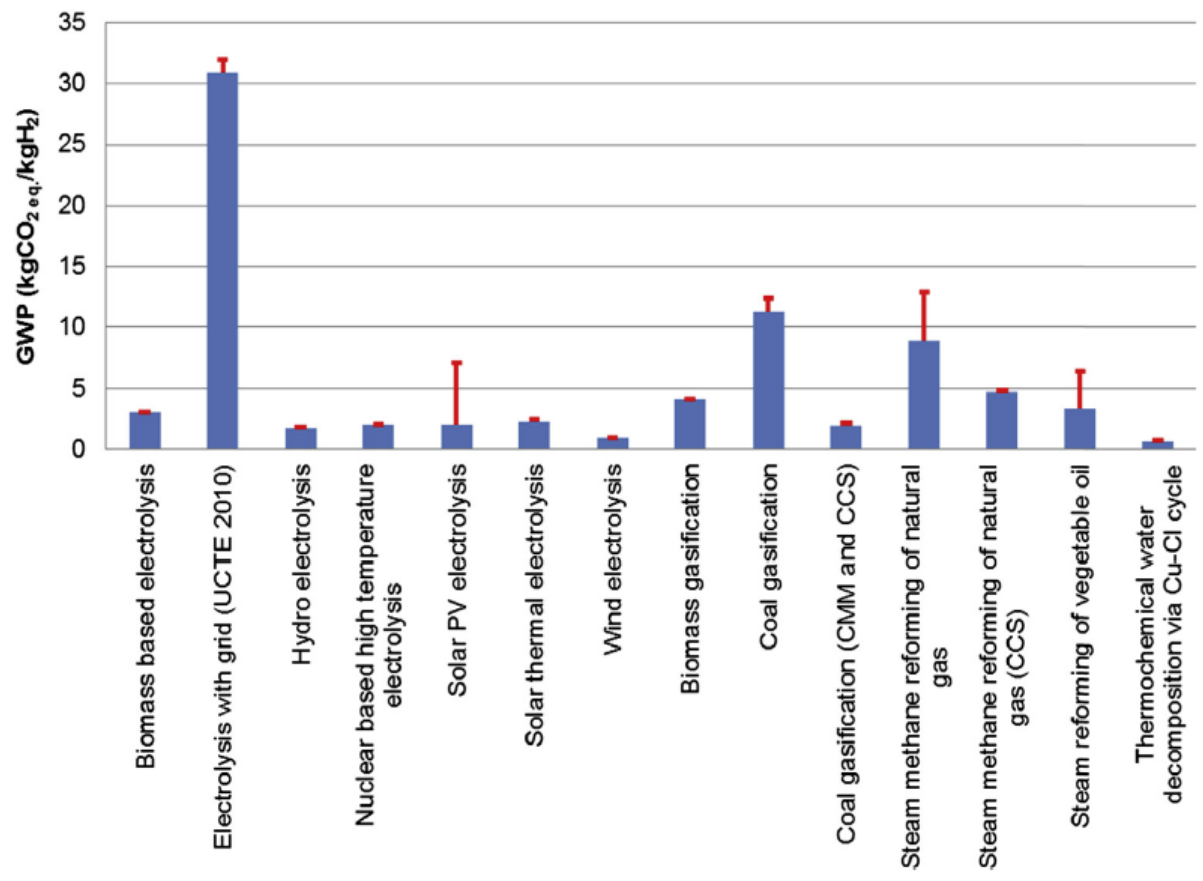

Figure 3: GWP for various $\mathrm{H}_{2}$ production technologies (taken from [42])

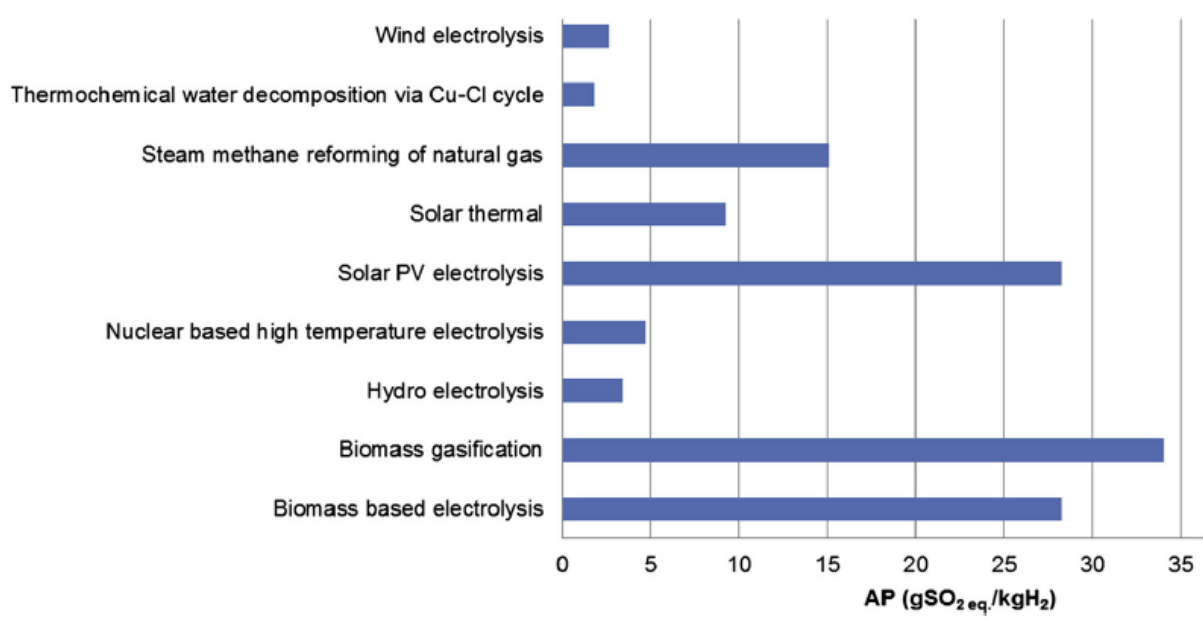

Figure 4: AP for various $\mathrm{H}_{2}$ production technologies (taken from [42]) 
ever, these technologies require different levels of development and scalability testing, but promise to be competitive [20]. Among them, it is worth mentioning the case of microbial electrolysis, since it can achieve a high efficiency in the production of hydrogen and is considered versatile in terms of the various alternatives of application [44].

As stated in Section 1, electrolysis has the ability to take direct advantage of the surplus electricity from renewable energy sources that is a fundamental step in the development of the hydrogen economy. So from now on, this paper will focus on this technology.

\section{Water electrolysis}

Electrolysis is the method through which the water molecule is separated into hydrogen and oxygen by applying an electric current [42]. Although there are different methods, which are introduced below, they share the same global reaction

$$
\mathrm{H}_{2} \mathrm{O}(\mathrm{l}) \longrightarrow \mathrm{H}_{2}(\mathrm{~g})+\frac{1}{2} \mathrm{O}_{2}(\mathrm{~g})
$$

\subsection{Alkaline electrolysis}

Alkaline electrolysis highlights among other technologies since it is the one with greater maturity and the larger commercial outreach [43]. The system is constituted by a pair of electrodes immersed in an alkaline solution, usually potassium hydroxide $(\mathrm{KOH})$ at a concentration of 25 to $30 \%$, and separated by a diaphragm. At the cathode water is split to form $\mathrm{H}_{2}$ and releasing hydroxide anions which pass through the diaphragm and recombine at the anode to form $\mathrm{O}_{2}$ according to the following reactions: 


$$
\begin{gathered}
2 \mathrm{H}_{2} \mathrm{O}(\mathrm{l})+2 \mathrm{e}^{-} \longrightarrow \mathrm{H}_{2}(\mathrm{~g})+2 \mathrm{OH}^{-}(\mathrm{aq}) \\
2 \mathrm{OH}^{-}(\mathrm{aq}) \longrightarrow \frac{1}{2} \mathrm{O}_{2}(\mathrm{~g})+2 \mathrm{e}^{-}+\mathrm{H}_{2} \mathrm{O} .
\end{gathered}
$$

\subsection{Proton Exchange Membrane electrolysis}

The electrolyte in this case is a polymeric membrane with acidic nature that allows exchange of protons $\left(\mathrm{H}^{+}\right)$, hence its name Proton Exchange Membrane (PEM). That membrane, along with the electrodes, form what is called Membrane Electrode Assembly (MEA). At the anode, water is oxidized to $\mathrm{O}_{2}$ and release protons that flow through the membrane and are reduced at the cathode to form $\mathrm{H}_{2}$ according to the following reactions [45]:

$$
\begin{gathered}
\mathrm{H}_{2} \mathrm{O}(\mathrm{l}) \longrightarrow \frac{1}{2} \mathrm{O}_{2}(\mathrm{~g})+2 \mathrm{H}^{+}(\mathrm{aq})+2 \mathrm{e}^{-} \\
2 \mathrm{H}^{+}(\mathrm{aq})+2 \mathrm{e}^{-} \longrightarrow \mathrm{H}_{2}(\mathrm{~g}) .
\end{gathered}
$$

\subsection{Solid Oxide Electrolysis (SOE)}

Both Alkaline and PEM electrolyzers are known as Low Temperature Electrolyzers (LTE). On the other hand, a third option, Solid oxide Electrolyzer (SOE), is known as High Temperature Electrolyzer (HTE). Although LTE is a mature technology, HTE has the distinction of performing electrolysis of water vapor at high temperatures, resulting in higher efficiencies compared to previous options. Moreover, it has the possibility of using waste heat instead of part of the elec-

tricity needed [46, 47]. Despite this, they are not ready to be commercialized because they have durability problems due to the severe conditions. The reactions occurring at the cathode and anode are as follows: 


$$
\begin{gathered}
\mathrm{H}_{2} \mathrm{O}(\mathrm{g})+2 \mathrm{e}^{-} \longrightarrow \mathrm{H}_{2}(\mathrm{~g})+\mathrm{O}^{2-} \\
\mathrm{O}^{2-} \longrightarrow \frac{1}{2} \mathrm{O}_{2}(\mathrm{~g})+2 \mathrm{e}^{-} .
\end{gathered}
$$

\subsection{Anion Exchange Membrane electrolysis (AEM)}

A technology that is being developed is the cell with Anion Exchange Membrane (AEM). Schematically it has the same structure of a PEM cell with the difference that the membrane transports anions $\mathrm{OH}^{-}$instead of protons $\mathrm{H}^{+}$. In that sense, the reactions that occur in the electrodes are the same as for the traditional alkaline cells [48]. AEM technology brings certain advantages compared to the latter ones $[49,50]$ :

1. They do not present precipitation of carbonates due to the lack of metallic cations.

2. They show lower ohmic losses because the AEM is thinner than traditional membranes.

3. The membrane is less expensive than the PEM one.

4. It is not necessary to use a concentrated $\mathrm{KOH}$ solution, making installation less critic and easier to operate.

In addition, due to its basic condition, this type of electrolyzers does not require platinum-group-metal (PGM) catalysts such as PEM cells. Instead, there are experiences using transition-metal catalysts with suitable performances, which makes it cheaper [51, 52, 53, 54]. Moreover, a possible advantage over the traditional alkaline electrolysers that is being studied is to be able to improve the purity of produced gases at high pressure [55]. 
A mathematical model was made by An et al [50] that was validated with experimental data found in the literature. In that work, the authors report that the performance of the cell improves at a higher exchange current density and liquid saturation and with a lower membrane thickness. However, a matter to be solved is the durability of the alkaline membrane since it has a low chemical stability $[49,56,57,58]$.

\subsection{Comparison of electrolytic methods}

The three main methods of electrolysis have various features and different stages of development, as can be seen in Table 3 .

Because of its long tradition, alkaline electrolyzers are nowadays sold in greater numbers, although PEM models are competing with them. As can be seen in Table 3 , the latter have important advantages over the former in relation to a higher current density, a greater operating range and a higher purity [45]. On the other hand, the biggest disadvantage of PEM electrolysers lies in the durability of the components [62] and in the higher costs associated with titanium-based contact elements, such as bipolar plates and current collectors, and the high iridium charge of the electrocatalyst for Oxygen Evolution Reaction (OER) in MEA [63]. Because of this, the greatest efforts in the latter are devoted to the search for new materials. In spite of greater efficiency, SOE electrolyzers are still being developed for commercialization so this technology will not be deeply analyzed. Its efficiency close to $100 \%$ (in practice it can reach values of $90 \%$ ) generates interest in the developments related to the improvement of durability and costs [64]. Despite these efforts, the SOE electrolysers are far from reaching commercialization status [65].

In the research carried out by Felgenhauer and Hamacher [66] to BMW, different companies and models of alkaline and PEM electrolyzers are compared until 
Table 3: Typical specifications of electrolizers (taken from [43] and updated with information from [59])

\begin{tabular}{|c|c|c|c|c|}
\hline Specification & Units & Alkaline & PEM & SOE \\
\hline Technology maturity & & $\begin{array}{c}\text { Widespread } \\
\text { commercialization }\end{array}$ & Commercialization & $\begin{array}{c}\text { Research \& } \\
\text { Development }\end{array}$ \\
\hline Cell temperature & ${ }^{\circ} \mathrm{C}$ & $60-80$ & $50-80$ & $900-1000$ \\
\hline Cell pressure & bar & $<30$ & $<30$ & $<30$ \\
\hline Current density & $\mathrm{A} \mathrm{cm}^{-2}$ & $<0.45$ & $1.0-2.0^{a}$ & $0.3-1.0$ \\
\hline Cell voltage & $\mathrm{V}$ & $1.8-2.4$ & $1.8-2.2$ & $0.95-1.3$ \\
\hline Voltage efficiency & $\%$ & $62-82$ & $67-82$ & $81-86$ \\
\hline Specific system energy consumption ${ }^{b}$ & $\mathrm{kWh} \mathrm{Nm}^{-3}$ & $4.2-4.8$ & $4.4-5.0$ & $2.5-3.5$ \\
\hline Minimum partial load & $\%$ & $10-40$ & $0-10^{c}$ & - \\
\hline Cell area & $\mathrm{m}^{2}$ & $3-3.6$ & $<0.13$ & $<0.06$ \\
\hline Hydrogen production per stack ${ }^{d}$ & $\mathrm{Nm}^{3} \mathrm{~h}^{-1}$ & $<1400$ & $<400$ & $<10$ \\
\hline Stack lifetime & $\mathrm{kh}$ & $55-120$ & $60-100$ & $8-20^{e}$ \\
\hline System lifetime & year & $20-30$ & $10-20$ & - \\
\hline Hydrogen purity & $\%$ & $>99.8$ & 99.999 & - \\
\hline Cold start-up time & $\min$ & 15 & $<15$ & $>60$ \\
\hline Investment costs & $€ \mathrm{~kW}^{-1}$ & $800-1500$ & $1400-2100$ & $>2000^{e}$ \\
\hline
\end{tabular}

${ }^{a}$ Typical commercial values, although laboratory experiments with a current density up to 20 $\mathrm{A} \mathrm{cm}^{-2}$ are reported [60].

${ }^{b}$ Excluding rectifier and utilities (0.4-0.8 $\mathrm{kWh} \mathrm{Nm}^{-3}$ )

${ }^{c}$ Vendors do not report a technical limit but it is known that there is gas contamination at high pressures and low current density that prevent reaching values close to 0 [61]

${ }^{d}$ According to a recent market survey

${ }^{e}$ High uncertainity due to pre-commercial status of SOE 
the first half of 2014. In Table 4, it can be seen some technical data of electrolyzers from nine companies: CETH2/Areva H2Gen, Hydrotechnik, Hydrogenics, ITM Power, McPhy Energy, NEL, Next Hydrogen, PERIC and Siemens.

For large-scale systems, there are configurations commercially available formed by several stacks allowing greater production than the ones listed in Table 3. Another advantage of this type of configuration is the possibility to have a wider range of operation.

Although it is not explicit in the table, Felgenhauer and Hamacher say that efficiency is between $52 \%$ and $62 \%$ for alkaline electrolyzers and $57-64 \%$ for PEM systems, at the beginning of life (BOL) and 10 bar outlet pressure. Taking into account that the average of the efficiency degradation of the models analyzed by Felgenhauer and Hamacher is double for the PEM type (1.57\%) than for the alkaline ones $(0.78 \%)$, the former difference becomes less important, leading to an even situation throughout the life of the system.

In the study mentioned, an economic evaluation of these systems is performed and better outcomes for the case of higher alkali production are obtained. In Fig. 5 investment cost and the cost of annual operation and maintenance per produced power of hydrogen (LHV) are observed. Moreover, the best cases (AEL25+), that represent Alkaline Electroyzers with a generation capacity over $25 \mathrm{~kg}_{\mathrm{H}_{2}} \mathrm{~h}^{-1}$, are shadowed.

Being the technologies in commercial state, Schalenbach et al [67] make a comparison between the alkaline electrolysis cells and the PEM cells together with a review of the challenges of both.

In Figure 6, it can be seen schemes of both cells with a similar configuration. The most important difference lies in the nature of the separator that divides the 
Table 4: Technical data of commercial electrolyzers (taken from [66])

\begin{tabular}{|c|c|c|c|c|}
\hline System & Generation capacity & $\begin{array}{l}\text { Efficiency } \\
\text { degradation }\end{array}$ & $\begin{array}{c}\text { Maximum output } \\
\text { pressure }\end{array}$ & Stack lifetime \\
\hline & $\mathrm{kgH}_{2} /$ hour & $\% /$ year & bar & hour \\
\hline \multicolumn{5}{|l|}{ Alkalines } \\
\hline A06 & 5.9 & 1.50 & 10 & 55000 \\
\hline A10 & 9.9 & 1.50 & 10 & 55000 \\
\hline $\mathrm{A} 25$ & 25.0 & 1.00 & 1 & 78840 \\
\hline $\mathrm{A} 27 \mathrm{~A}$ & 27.0 & 0.50 & 13 & 87600 \\
\hline A27B & 27.0 & 0.25 & 10 & 96000 \\
\hline A31 & 31.4 & 0.10 & 13 & 50000 \\
\hline A36 & 36.0 & 1.00 & 30 & 87600 \\
\hline A44 & 43.7 & 1.00 & 1 & 78840 \\
\hline A45 & 45.0 & 0.25 & 10 & 96000 \\
\hline A50 & 50.0 & 1.00 & 1 & 78840 \\
\hline A54 & 54.0 & 0.50 & 13 & 87600 \\
\hline \multicolumn{5}{|l|}{ PEM } \\
\hline P09 & 9.0 & 1.17 & 30 & 70080 \\
\hline $\mathrm{P} 11$ & 12.0 & 2.50 & 14 & 100000 \\
\hline $\mathrm{P} 21$ & 21.2 & 0.50 & 35 & 80000 \\
\hline $\mathrm{P} 22$ & 21.6 & 2.50 & 14 & 100000 \\
\hline $\mathrm{P} 47$ & 47.0 & 1.17 & 30 & 70080 \\
\hline
\end{tabular}

half-cells of $\mathrm{H}_{2}$ and $\mathrm{O}_{2}$ production: in the case of the alkaline electrolyzers, this is a porous diaphragm that allows the free circulation of the hydroxyls present in the alkaline solution, generally potassium hydroxide $(\mathrm{KOH})$, which floods the cell [68], while in the PEM cells, it is a solid polymeric electrolyte (SPE) that provides the necessary protons for the process [45].

Behind the separator, there are electrodes whose surface is covered with elec- 


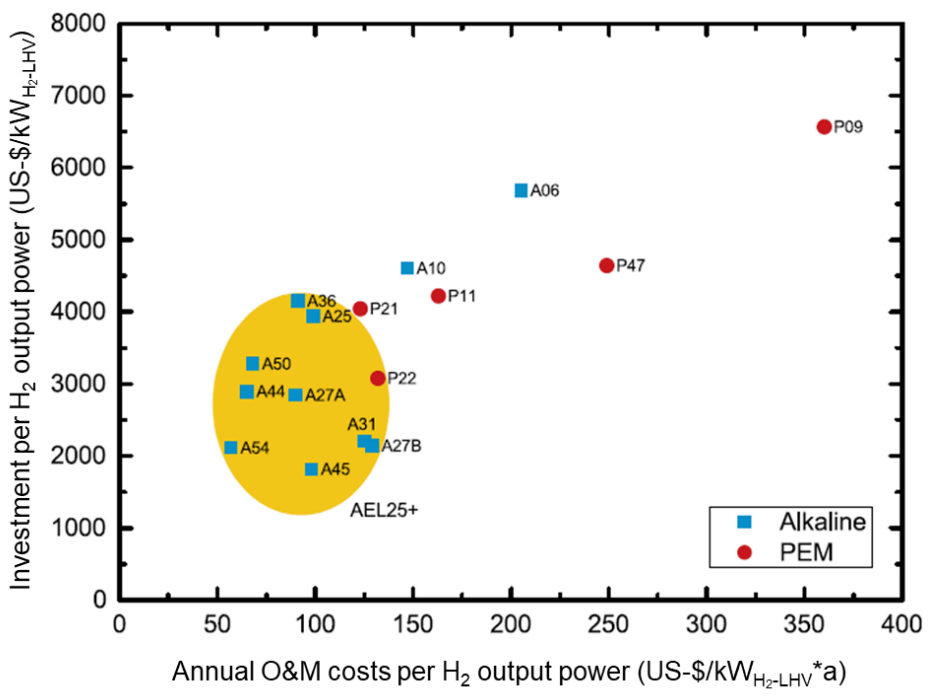

Figure 5: Investment cost and cost of operation and maintenance by produced power of $\mathrm{H}_{2}$ (taken from [66]). The best cases (AEL25+), that represent Alkaline Electroyzers with a generation capacity over $25 \mathrm{~kg}_{\mathrm{H}_{2}} \mathrm{~h}^{-1}$, are highlighted

trocatalysts that allow the reaction. These electrodes must be porous to allow the circulation of water, produced gases, electrons and ions [69]. In the case of the PEM cells and due to their acidity, only the platinum-group metals (PGM) have been tested commercially for being stable and having an acceptable ionic activity as electrocatalysts. However, the advances that have been made in the use of electrocatalysts with a transition metal base are promising. Such is the case of the transition metals of the first row $(\mathrm{Mn}, \mathrm{Fe}, \mathrm{Co}, \mathrm{Ni}, \mathrm{Cu})$ as calchogenides, phosphides, nitrides and carbides [70, 71]. In addition, the electrochemical properties of transition metal carbides (WC, $\mathrm{Mo}_{2} \mathrm{C}, \mathrm{TaC}, \mathrm{NbC}$ ) have been tested for HER at medium temperatures $\left(200-400^{\circ} \mathrm{C}\right)$ obtaining a proper activity although a demonstration is still needed under realistic conditions [72].

That is why the electrodes are commercially made with an SPE base coated 


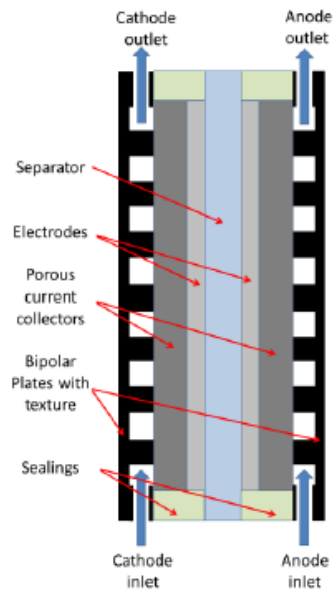

Figure 6: Schematic of an electrolytic cell (taken from [67]).

with platinum at the cathode and iridium at the anode. On the other hand, as the $\mathrm{KOH}$ solution provides the anions, the electrodes can be made as a metallic mesh, usually Ni. Moreover, stable catalysts made of $\mathrm{Ni}, \mathrm{Co}$ and $\mathrm{Fe}$ are much more abundant and cheaper than their PGM pairs [67].

Since the Ni electrodes allow a proper electrical conduction and have sufficient mechanical resistance, it is not necesary to use collectors in the alkaline electrolyzers, therefore the electrodes are connected directly to the bipolar plate. On the contrary, the electrodes of the PEM cell require the support of the collectors to ensure the conductivity and structural stability.

The problems of durability [73] in the PEM cells lie in the replacement of protons by other cations losing conductivity [74], the loss of dimensional properties under temperature and pressure [75], the degradation by the formation of HF [76] and the ohmic losses by the oxidation of Ti present in the collectors and bipolar plates [77]. In contrast, alkaline electrolyzers are intrinsically more durable but it is important to be careful with the Ni disolution when the cell potential falls below 
$1.23 \mathrm{~V}$, so it would be necessary to maintain a stand-by power that would hinder direct and isolated interconnection with renewable energies.

The study concludes that, for large-scale industrial water electrolysis, liquid alkaline electrolyzers seem to be more suitable because they are not limited to the use of precious and scarce metals. In turn, due to the different corrosion mechanisms in acidic and alkaline media, the latter show greater durability. Finally, the alkaline electrolyte is chemically stable and interchangeable, while the SPEs are vulnerable to the loss of conductivity due to impurities, chemical decomposition and thermomechanical deformation. As presented by the companies in Table 4, a tie situation can be observed in terms of the stack durability and a minor difference from the summary presented in Table 3 . This is not in accordance with what was stated before but it could be justified by the efficiency degradation which was pointed out by Felgenhauer and Hamacher [66].

The main issues of each of the technologies that has to be worked out, are the outlined next. For the case of PEM cells:

- Designing of SPE membranes more durable thermomechanically and chemically.

- Finding other suitable catalysts than Ir.

- Counteracting the corrosion and low conductivity of passive layers that degrade anodic collector bipolar plates.

- Lowering diffusivity in the solid phase of membranes for greater purity.

In contrast, the challenges for alkaline cells, which will then be discussed in Section 4, are outlined as follows: 
- Making porous electrodes that allow the effective evacuation of the bubbles and therefore decrease the ohmic fall.

- Optimizing porous alloys catalysts with $\mathrm{Ni}, \mathrm{Fe}$ and $\mathrm{Co}$.

- Preventing hydride formation and hydrogen embrittlement in Ni cathode.

- Reducing pores diameters of separators for greater purity.

\section{Developments in Alkaline electrolysis}

In recent decades, advances have been made in this type of electrolyzers called as advanced alkaline electrolyzers. The most important points of development are [21]:

- Zero-gap configuration. It consists of minimizing the distance between electrodes to reduce the ohmic losses.

- New materials for the diaphragm. Previously made of asbestos, the use of inorganic membranes is investigated. Some are based on antimony polyacid impregnated with polymers [78], on porous composite composed of a polysulfone matrix and $\mathrm{ZrO}_{2}$ (Zirfon) [79], or on polyphenil sulfide (Ryton) [80].

- Temperature increase. The temperature is increased to promote electrolytic conductivity and improve reaction kinetics at the electrodes.

- Electrocatalytic materials. Such materials are developed to reduce overpotentials at the electrodes. 
A computational analysis of the citations made in recent years on electrolysis was developed by Ogawa et al [81]. The results indicate that the amount of publications related to this technology is increasing, and that the areas of microbial electrolysis and catalysts in alkaline and PEM electrolyzers are attracting greater interest. It is clear that although alkaline electrolysis technology is widely known, there is still interest in developing improvements in different fields, some of which are presented below.

\subsection{High temperature and pressure electrolysis}

The electrolyzers are currently designed for stationary operation. In turn, there are electrolyzers that produce gases at atmospheric pressure or up to 30 bar. So compression stages are required for storage at high-pressure levels. Against this, the opinions are divided between those who propose to design electrolizers that produce directly the gases with greater pressure $[82,83]$ and those who assure that this is a loss of efficiency [84].

In the last group are Roy et al [84] who consider in their analysis the energy consumption in the auxiliary equipment and the loss of gas during the operation to conclude that atmospheric electrolyzers are more efficient compared to electrolyzers operating at pressures up to 700 bar. The percentage of increase in energy consumed reaches $16.66 \%$ at 700 bar, according to the calculations of the authors. At the same time, they consider that corrosion, hydrogen embrittlement, operation complexity, dynamic response and costs, make pressurized electrolyzers less favorable.

On the contrary, the first group claim that the energy needed to compress the gases grows more than the theoretical energy of dissociation of water. There are

even projects that try to demonstrate with pilot plants the realizability of such a 
Table 5: Development perspectives of selected parameters in alkaline electrolysis technology (taken from [83])

\begin{tabular}{|l|c|c|c|c|c|}
\hline Specification & Symbol & Unit & State of the art & $\begin{array}{c}\text { Short-term } \\
\text { Development }\end{array}$ & $\begin{array}{c}\text { Middle-term } \\
\text { Development }\end{array}$ \\
\hline \hline Temperature & $\vartheta$ & ${ }^{\circ} \mathrm{C}$ & $70-80$ & $80-90$ & $>90$ \\
\hline Pressure & $p$ & $\mathrm{bar}$ & 30 & $>60$ & $>100$ \\
\hline Current density & $i$ & $\mathrm{kA} / \mathrm{m}^{2}$ & $3-4$ & $6-8$ & $>10$ \\
\hline Cell voltage & $U$ & $\mathrm{~V}$ & $1.9-2.3$ & $1.8-2.1$ & $1.7-2.0$ \\
\hline Voltage efficiency & $\Phi$ & $\%$ & $64-78$ & $70-82$ & $74-87$ \\
\hline Spec. energy use, sys & $\Psi_{\text {sys }}$ & $\mathrm{kWh} / \mathrm{Nm}^{3}$ & $4.6-6.8$ & $4.5-6.4$ & $4.4-5.9$ \\
\hline Part load capacity & $\theta$ & $\%$ & 25 & $<15$ & $<10$ \\
\hline Operating life & $\tau$ & $\mathrm{h}$ & $<90000$ & $>100000$ & $>120000$ \\
\hline System durability & $\Pi$ & $\mathrm{y}$ & $<25$ & 30 & $>30$ \\
\hline
\end{tabular}

solution, as the case of Brandenburg University of Technology Cottbus [83]. In the presentation of the project, they define the perspectives on the technology of alkaline electrolysis, as shown in Table 5.

Allebrod et al [85] assure to have succeeded in improving the efficiency of alkaline systems with an operating state of $240{ }^{\circ} \mathrm{C}$ and 37 bar. In turn, they propose a new design with electrolyte inside a porous structure allowing current densities up to $2 \mathrm{Acm}^{-2}$ and voltages not exceeding $1.75 \mathrm{~V}$ (typical value in commercial equipment). On the other hand, in the cost analysis competitive prices are obtained by not using precious metals.

Ganley [86] also experimented with electrolytic cells of high pressure and temperature (up to 87 bar and $400{ }^{\circ} \mathrm{C}$ ). The results were promising given that the applied voltage is drastically reduced. However, the author raises objections about these results due to the possible mixture of products and corrosion of the electrodes that could have distorted the aforementioned values. Having said that, 
it is necessary to design new experiments that allow to explain the observed phenomena.

In conclusion, it is theoretically possible to increase the efficiency of the system by increasing the pressure and temperature but there are still technical issues to be solved, among which cross-contamination of gases and materials stability stands out, respectively.

\subsection{Overpotentials reduction}

The principle of alkaline electrolysis functioning has been widely described by several authors. In 2003, Ulleberg [87] proposed a model based on concepts of thermodynamics and heat transfer to obtain the package voltage, the produced gas flow rate and the thermal equilibrium of the system, as a function of the imposed current. These results were validated at the PHOEBUS plant in Jülich, where tests of photovoltaic cells, production and storage of hydrogen are carried out [88].

On the other hand, Ursúa and Sanchis [89] start from the same thermodynamic theory to define the ideal tension of water dissociation to construct an electrical model of the overpotentials. The final model has the same terms proposed by Ulleberg as can be seen in equation 1 , where $v_{e}$ is the voltage applied in the stack, $N_{s}$ is the number of cells in a series configuration, $v_{a c t}$ is the activation overpotential and $v_{\text {ohm }}$ is the ohmic overpotential:

$$
v_{e}=N_{s}\left(V_{\text {rev }}+v_{\text {act }}+v_{\text {ohm }}\right)
$$

The first overpotential, $v_{a c t}$, is due to the polarization of the electrodes because of the approximation of the electrolyte ions to the surface of the electrodes, what is known as double layer effect. In her doctoral thesis, Roy [90] proposes the 
calculation of the second overpotential, $v_{o h m}$ from the conductivity of the materials in the path of the current and the presence of gas bubbles. This means that said overpotential includes both the electrical and the ionic conductivity in the electrolyte.

On one hand, Zouhri and Lee [91] propose a model to investigate the effects of properties of different materials on the ohmic overpotential, which influences the exergetic efficiency of alkaline electrolysis. In their work, it is shown that parameters such as membrane resistivity, distance between electrodes, bubbles, $\mathrm{KOH}$ concentration and temperature affect such overpotential. It is concluded that the greatest loss of efficiency is due, in order of priority, to:

1. The presence of hydrogen bubbles on the surface of the electrode

2. The ionic resistivity of the electrolyte

3. The presence of oxygen bubbles

4. Electrodes distance

5. Membrane (or diaphragm) resistivity

Alternatively, a way to reduce ohmic overpotentials is the introduction of an intermediate electrode so the reduction and oxidation of water occur in successive processes instead of in simultaneous ones. For example, in Japan, Choi et al [92] propose a cell of three electrodes submerged in an alkaline medium: metal hydride $(\mathrm{MH})$, negative; manganese dioxide $\left(\mathrm{MnO}_{2}\right)$, intermediate; and nickel hydroxide $\left(\mathrm{Ni}(\mathrm{OH})_{2}\right)$, positive. This idea was developed taking the experience made in other studies of the inclusion of a third electrode in the water splitting thermochemical cycles $[93,94]$. The general reactions of each half-cell are 


$$
\begin{aligned}
& \text { OER: } 2 \mathrm{MnO}_{2}+\mathrm{H}_{2} \mathrm{O} \longrightarrow 2 \mathrm{MnOOH}+\frac{1}{2} \mathrm{O}_{2} \text {, } \\
& \text { HER: } 2 \mathrm{MnOOH} \longrightarrow 2 \mathrm{MnO}_{2}+\mathrm{H}_{2} .
\end{aligned}
$$

By having an intermediate electrode that separates the reactions, two objectives are achieved: a) higher purity, since the gases are produced in different steps, and b) lower ohmic overpotential, by the use of a thinner separator. In this work, voltage levels below $1.6 \mathrm{~V}$ were reached at $60^{\circ} \mathrm{C}$, resulting in a potentially more efficient production of hydrogen and higher purity.

One way to reduce construction costs is to increase the current density. In order to achieve this goal, it is necessary to counteract the overpotentials so as not to lose efficiency. This is why this particular topic attracts the greatest interest currently. Particularly, as will be presented in Section 4.4, the issues about the materials of the electrodes, catalysts and their structures.

\subsection{Impact of electric input fluctuation}

The study of the response to variable input currents is of great interest given the attention caused by the interconnection of electrolyzers with renewable energies. The more direct the connection between them, the higher efficiency can be achieved in the storage of energy in the form of hydrogen. While there are certain investigations that study the response of electrolyzers to the change in the power supply such as a complete interruption or an impulse [95, 96, 97, 98], there is not much information about it [99].

Dobó and Palotás [100, 101] developed a series of experiments to characterize the response of an alkaline electrolysis cell to fluctuations in voltage and current. The electrolytic cell consisted of a closed container filled with $30 \mathrm{wt}$. \% potassium 
hydroxide solution with flat plate stainless steel electrodes. In the former case, the cell was fed with a sinusoidal voltage signal with amplitude $a$ and frequency $f$ mounted on a direct voltage $U_{D C}$. With an amplitude between 0 and $2 \mathrm{~V}$, a frequency between $1 \mathrm{~Hz}$ and $5000 \mathrm{~Hz}$ and a direct voltage between $1.4 \mathrm{~V}$ and $2.8 \mathrm{~V}$, 6512 experiments lasting $15 \mathrm{~s}$ were carried out. In each case, the electric power delivered and the gases produced were calculated, the second ones as a function of the pressure change in the cell. The results obtained show that at greater amplitude $a$ and frequency $f$, the efficiency of the cell decreases. In turn, $U_{D C}$ values are found in which the efficiency is maximum (around 2.2V). Efficiency is defined as

$$
\eta=100 Q\left[\frac{V_{m} P}{U^{0} F}\left(\frac{1}{z_{H_{2}}}+\frac{1}{z_{O_{2}}}\right)\right]^{-1},
$$

where $Q$ is the measured flow of gases produced, $V_{m}$ is the molar volume of the ideal gases for normal conditions, $U^{0}$ is the theoretical decomposition voltage of water, $F$ is the Faraday constant and $z$ is the charge number. A degradation of efficiency is obtained with respect to that corresponding to the DC operation of up to $20 \%$. However, there are work zones in which the efficiency drops due to the fluctuation in the input $(<2 \%)$ can be considered negligible. It is concluded that it is possible to accept fluctuation in the tension but it is recommended to soften the ripple to obtain better results.

In the second case, the cell was fed with several current waveforms (sine, triangle, sawtooth and square) characterized by the direct current $I_{D C}$, the root mean square (rms) value $I_{r m s}$ and the frequency $f$. In turn, a ripple factor $r$ is defined as the relationship between the rms value of the $I_{r m s}$ alternating component and the continuous $I_{D C}$ value, thus comparing the different waveforms.

For frequencies between $1 \mathrm{~Hz}$ and $10 \mathrm{kHz}$, direct current between $1 \mathrm{kA} \mathrm{m}^{-2}$ and $5 \mathrm{kA} \mathrm{m}^{-2}$ and for amplitudes of the alternating component between $0 \mathrm{~A} \mathrm{~m}^{-2}$ 
to $I_{D C}, 4620$ experiments were performed. The results obtained mark a drop in efficiency (similarly calculated as in the previous case) with the increase of the direct current. In turn, there is a decrease in efficiency with the ripple factor (e.g. for $I_{D C}=4 \mathrm{kA} \mathrm{m}^{-2}$ and $f=1 \mathrm{kHz}$, the efficiency has a relative decrease of up to $16 \%$ with $r=100 \%)$. This is explained considering that the production of gases is directly related to $I_{D C}$, while the alternating component increases the power consumed at the same $I_{D C}$. Although frequency has a smaller participation, it is highlighted that at higher $f$ an improvement in efficiency is achieved (e.g. $I_{D C}=$ $2 \mathrm{kA} \mathrm{m}^{-2}$ and $r=100 \%$, the efficiency is $48.5 \%$ for the case of continuous and it increases to $50 \%$ for $f=10 \mathrm{kHz}$ ).

\subsection{Electrode materials}

The electrodes are usually made of nickel because of its stability. However, it is necessary to counteract the deactivation mechanism. Some solutions are the iron coating [102] or vanadium disolution [103].

On the other hand, the use of electrocatalysts allows, in addition to stabilizing the electrodes, to reduce the ohmic overpotential. Zeng and Zhang [104] present some examples of anode (Table 6) and cathode (Table 7) materials used in commercial electrolyzers.

In turn, there are those who claim that, for the estimated global capacity of electrolyzers, it will be necessary to dispense with noble metals [116]. Therefore, there are experiences using stainless steel electrodes seeking to improve their electrical efficiency [117]. Besides, Cruden et al [118] compare electrodes based on Nickel with Molybdenum-Resorcinol-Formaldehyde (Mo RF) and other Ni-C-Ptmade electrodes. It is concluded that the proposed Ni-Mo RF can be a replacement for the existing Ni-C-Pt electrodes, the latter being more expensive. 
Table 6: Oxygen overpotential of different electrode materials [taken from [104]]

\begin{tabular}{|l|c|c|c|c|c|c|c|}
\hline Composition formula & Method & $\mathrm{T}\left({ }^{\circ} \mathrm{C}\right)$ & Electrolyte & $\mathrm{C}\left(\mathrm{mol} \mathrm{dm}^{-3}\right)$ & $\mathrm{j}\left(\mathrm{Am}^{-2}\right)$ & $\eta_{\text {oxygen }}(\mathrm{mV})$ & $\mathrm{Ref}$. \\
\hline $\mathrm{Ni}+$ Spinel type $\mathrm{Co}_{3} \mathrm{O}_{4}$ & Thermo-decomposition & 25 & $\mathrm{KOH}$ & 1 & 1000 & $235 \pm 7$ & {$[105]$} \\
$\mathrm{Ni}+\mathrm{La}$ doped $\mathrm{Co}_{3} \mathrm{O}_{4}$ & Thermo-decomposition & 25 & $\mathrm{KOH}$ & 1 & 1000 & $224 \pm 8$ & {$[105]$} \\
$\mathrm{MnOx}$ modified $\mathrm{Au}$ & Electro-deposition & 25 & $\mathrm{KOH}$ & 0.5 & 100 & 300 & {$[106]$} \\
$\mathrm{Li} 10 \%$ doped $\mathrm{Co}_{3} \mathrm{O}_{4}$ & Spray pyrolysis & $\mathrm{RT}$ & $\mathrm{KOH}$ & 1 & 10 & 550 & {$[107]$} \\
$\mathrm{Ni}$ & N/A & 90 & $\mathrm{KOH}$ & $50 \mathrm{wt} \%$ & 1000 & 300 & {$[108]$} \\
$\mathrm{La}_{0.5} \mathrm{Sr}_{0.5} \mathrm{CoO}_{3}$ & Spray-stiner & 90 & $\mathrm{KOH}$ & $50 \mathrm{wt} \%$ & 1000 & 250 & {$[108]$} \\
$\mathrm{Ni}_{0.2} \mathrm{Co}_{0.8} \mathrm{LaO}_{3}$ & Plasma jet projection & 90 & $\mathrm{KOH}$ & $50 \mathrm{wt} \%$ & 1000 & 270 & {$[108]$} \\
\hline
\end{tabular}

Table 7: Hydrogen overpotential of different electrode materials [taken from [104]]

\begin{tabular}{|l|c|c|c|c|c|c|c|}
\hline Composition formula & Method & $\mathrm{T}\left({ }^{\circ} \mathrm{C}\right)$ & Electrolyte & $\mathrm{C}\left(\mathrm{mol} \mathrm{dm}^{-3}\right)$ & $\mathrm{j}\left(\mathrm{Am}^{-2}\right)$ & $\eta_{\text {hydrogen }}(\mathrm{mV})$ & Ref. \\
\hline Ni-Fe-Mo-Zn & Co-deposition & 80 & $\mathrm{KOH}$ & 6 & 1350 & 83 & {$[109]$} \\
Ni-S-Co & Electro-deposition & 80 & $\mathrm{NaOH}$ & $28 \mathrm{wt} \%$ & 1500 & 70 & {$[110]$} \\
$\mathrm{Ni} 50 \%-\mathrm{Zn}$ & Electro-deposition & $\mathrm{N} / \mathrm{A}$ & $\mathrm{NaOH}$ & 6.25 & 1000 & 168 & {$[111]$} \\
$\mathrm{MnNi}_{3.6} \mathrm{Co}_{0.75} \mathrm{Mn}_{0.4} \mathrm{Al}_{0.27}$ & Arc melting & 70 & $\mathrm{KOH}$ & $30 \mathrm{wt} \%$ & 1000 & 39 & {$[112]$} \\
$\mathrm{Ti}_{2} \mathrm{Ni}$ & Arc melting & 70 & $\mathrm{KOH}$ & $30 \mathrm{wt} \%$ & 1000 & 16 & {$[113]$} \\
$\mathrm{Ni} 50 \% \mathrm{Al}$ & Melting & 25 & $\mathrm{NaOH}$ & 1 & 1000 & 114 & {$[114]$} \\
$\mathrm{Ni} 75 \% \mathrm{Mo} 25 \%$ & Co-deposition & 80 & $\mathrm{KOH}$ & 6 & 3000 & 185 & {$[115]$} \\
$\mathrm{Ni} 80 \% \mathrm{Fe} 18 \%$ & Co-deposition & 80 & $\mathrm{KOH}$ & 6 & 3000 & 270 & {$[115]$} \\
$\mathrm{Ni} 73 \% \mathrm{~W} 25 \%$ & Co-deposition & 80 & $\mathrm{KOH}$ & 6 & 3000 & 280 & {$[115]$} \\
$\mathrm{Ni} 60 \% \mathrm{Zn} 40 \%$ & Co-deposition & 80 & $\mathrm{KOH}$ & 6 & 3000 & 225 & {$[115]$} \\
$\mathrm{Ni} 90 \% \mathrm{Cr} 10 \%$ & Co-deposition & 80 & $\mathrm{KOH}$ & 6 & 3000 & 445 & {$[115]$} \\
\hline
\end{tabular}


Table 8: Main electrocatalyst materials and their current development [taken from [119]]

\begin{tabular}{|l|l|l|l|}
\hline Material & Activity & Stability & Status \\
\hline \hline Raney Ni & Sufficient activity & $\begin{array}{l}\text { Deactivation after intermittent opera- } \\
\text { tion }\end{array}$ & Commercially used \\
\hline $\mathrm{NiCo}, \mathrm{NiFe}$ & $\begin{array}{l}\text { High activity, which can be further im- } \\
\text { proved upon alloying with rare earths }\end{array}$ & $\begin{array}{l}\text { Better stability than Raney Ni, but still } \\
\text { not optimal }\end{array}$ & Laboratory applications \\
\hline $\mathrm{NiFe}_{2} \mathrm{O}_{4}$ & Very high activity & Long term stability & $\begin{array}{l}\text { Applied in lab-scale electrolysis with } \\
\text { polymeric membrane }\end{array}$ \\
\hline $\mathrm{NiMo}$ & Very high activity & Long term stability & $\begin{array}{l}\text { Pyrophoric material: inappropriate for } \\
\text { commercialization }\end{array}$ \\
\hline$(\mathrm{Ni}, \mathrm{Co}) \mathrm{W}$ & High activity & Unknown & Laboratory applications \\
\hline $\mathrm{Co}_{2} \mathrm{Si}$ & Very high activity & Unknown & Laboratory applications \\
\hline $\mathrm{Ni}_{3} \mathrm{~N}$ & High activity & Unknown & Laboratory applications \\
\hline
\end{tabular}

As stated previously, the study of catalysts is receiving increasing interest. As stated by Sapountzi et al [119], the worldwide development of hydrogen production by electrolysis is limited by the search for stable, active and abundant electrocatalysts that allow intermittent conditions. The authors present in Table 8 the main electrocatalyst materials and their current development. Another issue that is being investigated is the use of nanostructures to obtain higher efficiencies or decrease the amount of precious metals needed. Some examples are the deposition of $\mathrm{Pd}$ and $\mathrm{Ru}$ [120], the incorporation of $\mathrm{NiO}$ into a Ni-P matrix [121], the use of $\mathrm{Ni}$ nanoparticles on carbon nanotubes [122] and the development of $\mathrm{RuO} 2-\mathrm{NiO}$ nanorod arrays on a Ni foam substrate [123]. Table 9 shows the latest developments in the use of nanostructures showing the variety of forms and materials. This list is not exhaustive given the large dispersion.

\subsection{Gas-purity dependence}

Haug et al [131] developed a series of experiments to analyze the variation of the volumetric concentration of $\mathrm{H}_{2}$ in $\mathrm{O}_{2}$ at the outflow of a zero-gap alkaline 
Table 9: Comparison of works using nanostructures to obtain higher electrolysis efficciencies

\begin{tabular}{|c|c|c|c|c|c|}
\hline Material & Nanostructure & HER/OER ${ }^{a}$ & Activity & Stability & Ref \\
\hline $\mathrm{CoP}$ & $\begin{array}{l}\text { Nanosheet@microwire } \\
\text { array on Nickel foam }\end{array}$ & OER & $\begin{array}{l}\text { High activity }(296 \mathrm{mv} \\
@ 100 \mathrm{~mA})\end{array}$ & At least $65 \mathrm{~h}$ & [124] \\
\hline $\mathrm{NiWO}_{4}$ & Nanowire on Ti mesh & Both & $\begin{array}{l}\text { Good activity (101mV for HER } \\
\text { and 322mV for OER @ 20mA) }\end{array}$ & - & [125] \\
\hline $\mathrm{CoTe}_{2}-\mathrm{MnTe}_{2}$ & Hybrid nanowire on Ti mesh & OER & $\begin{array}{l}\text { Sufficient activity } \quad(310 \mathrm{mV} \\
\text { @ } 50 \mathrm{~mA})\end{array}$ & At least $60 \mathrm{~h}$ & [126] \\
\hline $\mathrm{Fe}-\mathrm{NiCr}_{2} \mathrm{O}_{4 /} \mathrm{NF}$ & Fe doped nanoparticles film & OER & $\begin{array}{l}\text { Good activity (228mV@20mA } \\
\text { and 318mV@ @500mA) }\end{array}$ & At least $60 \mathrm{~h}$ & [127] \\
\hline $\mathrm{CoP}_{3}$ & Nanowire array & HER & $\begin{array}{l}\text { Sufficient activity } \quad(76 \mathrm{mV} \\
\text { @ } 10 \mathrm{~mA})\end{array}$ & At least $60 \mathrm{~h}$ & [128] \\
\hline $\mathrm{CoP}$ & Nanosheet on carbon cloth & Both & $\begin{array}{l}\text { High activity ( } 52 \mathrm{mV} \text { for HER } \\
\text { and } 300 \mathrm{mV} \text { for OER @ } 10 \mathrm{~mA})\end{array}$ & - & [129] \\
\hline $\mathrm{PtCo}-\mathrm{Co} / \mathrm{TiM}$ & $\begin{array}{l}\text { Ultrafine alloy decorated } \\
\text { nanowire }\end{array}$ & HER & $\begin{array}{l}\text { Superior to Pt-based elec- } \\
\text { trocatalysts ( } 70 \mathrm{mV} @ 46.5 \mathrm{~mA})\end{array}$ & At least $50 \mathrm{~h}$ & [130] \\
\hline
\end{tabular}

${ }^{a}$ Tested in Hydrogen or Oxygen Evolution Reaction

electrolyzer. In this way, states of operation that define the following trends are achieved:

- The reduction in the electrolyte recirculation flow rate allows less impurities.

- A rise in the electrolyte concentration decreases the hydrogen content in oxygen.

- An increase in the temperature of the electrolyte implies less impurities.

It is necessary to clarify that these tendencies are delimited by other relations of commitment, as ohmic overpotential or properties of materials.

Another idea investigated is to know the change of the impurities with three configurations of the circuit. The first and traditional one is the mixing of the 
electrolyte recirculation circuits to the cell and the interconnection of both gas separators (mixed). The second one is the independence of recirculations and gas separators, while the third one keeps the recirculation circuits separated but allows the interconnection of the gas separators (partly separated). It is observed that there is an improvement in the purity when passing to separate recirculation circuits while it is not considerable when the gas separators are independent. However, the separation of the recirculation circuits does not allow the equalization of $\mathrm{KOH}$ concentrations necessary for the suitable performance of the cell. That is why two solutions that improve the purity are proposed:

- Partly separated method at low current densities (when impurities are higher) and change to mixed method when higher current densities are reached.

- Period cycling of the order of half an hour between the methods partly separated and mixed to achieve an improvement in the purity with respect to the traditional method.

\section{Discussions}

As presented in the current review, there are interesting alternative methods for the production of hydrogen with virtually zero emissions, among them highlighting the production from biomass and electrolysis. Its biggest disadvantage is the economic cost superior to industrial processes such as the SMR in both construction and operation. It can be seen that these three technologies will coexist in the medium term, waiting for the proportion of SMR to gradually decrease, generating two important niches to be filled by the other two methods: mass production of hydrogen for industry and mobility from biomass, and electrolysis as an energy buffer for renewable sources. 
Within the area of electrolysis, a comparative analysis of the various existing technologies was carried out. Advantages and disadvantages of the two commercially available methods have been pointed out, observing opinions of authors in favor of one and against another indistinctly. It is our opinion that both technologies have benefits that lead to their use in different situations: in the case of alkaline electrolyzers, more developed and tested, they are usable as large installations for the stabilization of electrical networks or directly connected to large wind or solar farms. On the other hand, for PEM electrolyzers, with better dynamics and gas quality, it is expected that they can be used as an intermediate energy buffer in industrial plants or at a residential level. In any case, the need to continue research lines to increase their efficiency and reduce their costs is highlighted. Among them is the study of materials for electrodes, electrocatalysts and separators. The other two technologies in development, the SOE and AEM electrolyzers, must overcome the durability barriers in order to compete with the previous ones in the medium to long term.

\section{Conclusions}

The search for alternative methods of power generation and transport has developed the concept of hydrogen economy. While today hydrogen is obtained mainly from hydrocarbons, new technologies to achieve lower GHG emissions are being developed and consolidated. This paper summarizes the different methods of hydrogen production with emphasis on the current status of alkaline electrolysis. Among hydrogen methods, electrolysis stands out for ease of connection to renewable energies, obtainable purity and their existing but nascent commercialization. 
In this paper, current lines of research on alkaline electrolyzers are discussed as it is the ecofriendly-technology with the highest maturity so far. Nevertheless, it requires improvements to be competitive against the production of fossil hydrogen, which means lowering construction and operating costs. The former depends mainly on the materials of the electrodes, so simple or coated non-precious metals are proposed. The later are strongly linked to the efficiency of the system which implies reducing ohmic overpotentials and gases cross-linking of gases. For this purpose, there are several proposals that will need to be deeply discused and analysed to find the optimum point of operation of alkaline electrolyzers.

The public has to be aware of the importance of reducing the GHG emissions. The hydrogen economy and renewable energies are, until today, the best solution. The development of these technologies needs the coworking between politics, business and science. The aim of this paper is to give a concise and precise idea of the latest progress around the world related to hydrogen economy and, specially, electrolysis in order to encourage the development and investigation in this important matter.

\section{References}

[1] International Energy Agency, 9, rue de la Fédération, 75739 Paris Cedex 15, France, Key world energy statistics 2017 (2016).

[2] SBC Energy Institute, Electricity Storage FactBook, White paper, http://energystorage.org/resources/sbc-energy-institute-electricity-storagefactbook (2013).

[3] T. Mahlia, T. Saktisahdan, A. Jannifar, M. Hasan, H. Matseelar, A review of 
available methods and development on energy storage: technology update, Renewable and Sustainable Energy Reviews 33 (2014) 532-545.

[4] S. Sharma, S. K. Ghoshal, Hydrogen the future transportation fuel: From production to applications, Renewable and Sustainable Energy Reviews 43 (2015) 1151-1158.

[5] R. Chaubey, S. Sahu, O. James, S. Maity, A review on development of industrial process and emerging techniques for production of hydrogen from renewable and sustainable sources, Renewable and Sustainable Energy Reviews 23 (2015) 443-462.

[6] M. A. Abdalla, S. Hossain, O. B. Nisfindya, A. A. T., M. Dawoodb, A. K. Azada, Hydrogen production, storage, transportation and key challenges with applications: A review, Energy Conversion and Management 165 (2018) 602-627.

[7] F. Zhang, P. Zhao, M. Niu, J. Maddy, The survey of key technologies in hydrogen energy storage, International Journal of Hydrogen Energy 41 (2016) $14535-14552$.

[8] S. Dutta, A review on production, storage of hydrogen and its utilization as an energy resource, Journal of Industrial and Engineering Chemistry 20 (2014) 1148-1156.

[9] K. Mazloomi, C. Gomes, Hydrogen as an energy carrier: Prospects and challenges, Renewable and Sustainable Energy Reviews 16 (2012) 30243033. 
[10] FreedomCAR \& Fuel partnership, Hydrogen production: Overview of technology options, https://www1.eere.energy.gov/ hydrogenandfuelcells/pdfs/h2_tech_roadmap.pdf (2009).

[11] S. Schiebahn, T. Grube, M. Robinius, V. Tietze, B. Kumar, D. Stolten, Power to gas: Technological overview, systems analysis and economic assessment for a case study in Germany, International Journal of Hydrogen Energy 40 (2015) 4285-4294.

[12] G. Gahleitner, Hydrogen from renewable electricity: An international review of power-to-gas pilot plants for stationary applications, International Journal of Hydrogen Energy 38 (2013) 2039-2061.

[13] M. Ball, M. Weeda, The hydrogen economy - vision or reality?, International Journal of Hydrogen Energy 40 (2015) 7903-7919.

[14] U. Albrecht, M. Altmann, J. Michalski, T. Raksha, W. Weindorf, Analyse der Kosten Erneuerbarer Gase, Ponte Press, Ottobrunn, Germany, 2013.

[15] Nationale Organisation Wasserstoff, Berlin, Germany, Integration von Wind-Wasserstoff-Systemen in das Energiesystem (2014).

[16] HyUnder, Assessment of the potential, the actors and relevant business cases for large scale and long term storage of renewable electricity by $\mathrm{H}_{2}$ underground storage in Europe - executive summary (2014).

[17] M. L. Arlt, G. F. Cardoso, D. Weng, Hydrogen storage applications in industrial microgrids, in: 2017 IEEE Green Energy and Smart Systems Conference (IGESSC), 2017, pp. 1-6. doi:10.1109/IGESC.2017.8283465. 
[18] A. Ganeshan, D. G. Holmes, L. Meegahapola, B. P. McGrath, Enhanced control of a hydrogen energy storage system in a microgrid, in: 2017 Australasian Universities Power Engineering Conference (AUPEC), 2017, pp. 1-6. doi:10.1109/AUPEC.2017.8282434.

[19] F. Mueller-Langer, E. Tzimas, M. Kaltschmitt, S. Peteves, Technoeconomic assessment of hydrogen production processes for the hydrogen economy for the short and medium term, International Journal of Hydrogen Energy 32 (2007) 3797-3810.

[20] P. Nikolaidis, A. Poullikkas, A comparative overview of hydrogen production processes, Renewable and Sustainable Energy Reviews 67 (2017) 597_ 611.

[21] A. Ursúa, Hydrogen production from water electrolysis: Current status and future trends, Proceedings of the IEEE 100 (2012) 410-426.

[22] O. Schmidt, A. Gambhir, I. Staffell, A. Hawkes, J. Nelson, S. Few, Future cost and performance of water electrolysis: An expert elicitation study, International Journal of Hydrogen Energy 42 (2017) 30470-30492.

[23] D.-Y. Lee, A. Elgowainy, Q. Dai, Life cycle greenhouse gas emissions of hydrogen fuel production from chlor-alkali processes in the United States, Applied Energy 217 (2018) 467-479.

[24] S. K. Ngoh, D. Njomo, An overview of hydrogen gas production from solar energy, Renewable and Sustainable Energy Reviews 16 (2012) 6782-6792.

[25] J. Holladay, J. Hu, D. King, Y. Wang, An overview of hydrogen production technologies, Catalysis Today 139 (2009) 244-260. 
[26] K. McHugh, Hydrogen production methods, MPR Associates Inc. (2005) 41.

[27] T. Paulmier, L. Fulcheri, Use of non-thermal plasma for hydrocarbon reforming, Chemical Engineering Journal 106 (2005) 59-71.

[28] B. Rozmiarek, Hydrogen generation from biomass-derived carbohydrates via aqueous phase reforming process, Tech. rep., U.S. Department of Energy, Washington DC (2008).

[29] Fuel cells and infrastructure technologies program, multi-year research, development and demonstration plan, Tech. rep., U.S. Department of Energy (2007).

[30] B. Sørensen, Hydrogen and Fuel Cells Emerging Technologies and Applications, Elsevier Academic Press, 2005.

[31] N. A. of Science, The Hydrogen Economy: Opportunities, Costs, Barriers, and R\&D needs, Natl. Academies Press, Washington DC, 2004.

[32] T. Laurinavichene, S. Kosourov, M. Ghirardi, M. Seibert, A. Tsygankov, Prolongation of $\mathrm{H}_{2}$ photoproduction by immovilized, sulfurlimited chlamydomonas reinhardtii cultures, Journal of Biotechnology (2008) 275-277.

[33] K. Kovács, G. Maróti, G. Rákhely, A novel approach for biohydrogen production, International Journal of Hydrogen Energy 31 (2006) 1460-1468.

[34] D. Call, B. Logan, Hydrogen production in a single chamber microbial 
electrolysis cell lacking a membrane, Environmental Science and Technology 42 (2008) 3401-3406.

[35] J. Turner, G. Sverdrup, M. Mann, P.-C. Maness, B. Kroposki, M. Ghirardi, R. Evans, D. Blake, Renewable hydrogen production, International Journal of Hydrogen Energy 32 (2008) 379-407.

[36] M.-R. de Valladares, Global trends and outlook for hydrogen, International Energy Agency, December 2017.

[37] J. Turner, T. Deutsch, J. Head, P. Vallett, Photoelectrochemical water systems for $\mathrm{H}_{2}$ production, in: DOE Hydrogen Program Annual Merit Review, U.S. Department of Energy, Washington DC, http://www.hydrogen.energy.gov/pdfs/review07/pd_ 10_turner.pdf (2007).

[38] P. Parthasarathy, S. Narayanan, Hydrogen production from steam gasification of biomass: Influence of process parameters on hydrogen yield - a review, Renewable Energy 66 (2014) 570-579.

[39] S. E. Hosseini, M. A. Wahid, Hydrogen production from renewable and sustainable energy resources: Promising green energy carrier for clean development, Renewable and Sustainable Energy Reviews 57 (2016) 850866.

[40] J. Levene, M. Mann, R. Margolis, A. Milbrandt, An analysis of hydrogen production from renewable electricity sources, Solar energy 84 (2007) 773780. 
[41] H2A: Hydrogen Analysis Production Case Studies, Current Central Hydrogen Production from Natural Gas without $\mathrm{CO}_{2}$ Sequestration version 3.2018, https://www.nrel.gov/hydrogen/h2a-production-case-studies.html (2018).

[42] R. Bhandari, C. Trundewind, P. Zapp, Life cycle assessment of hydrogen production via electrolysis - a review, Journal of Cleaner Production 85 (2014) 151-163.

[43] I. Dincer, C. Acar, Review and evaluation of hydrogen production methods for better sustainability, International Journal of Hydrogen Energy 40 (2014) 11094-11111.

[44] Y. Zhang, I. Angelidaki, Microbial electrolysis cells turning to be versatile technology: Recent advances and future challenges, Water Research 56 (2014) 11-25.

[45] M. Carmo, D. L. Fritz, J. Mergel, D. Stolten, A comprehensive review on PEM water electrolysis, International Journal of Hydrogen Energy 38 (2013) 4901-4934.

[46] S. P. Badwal, S. Giddey, C. Munnings, Hydrogen production via solid electrolytic routes, Wiley Interdisciplinary Reviews: Energy and Environment 2 (2013) 473-487.

[47] M. Laguna-Bercero, Recent advances in high temperature electrolysis using solid oxide fuel cells: A review, Journal of Power Sources 203 (2012) 4-16. 
[48] L. Xiao, S. Zhang, J. Pan, C. Yang, M. He, L. Zhuang, J. Lu, First implementation of alkaline polymer electrolyte water electrolysis working only with pure water, Energy \& Environmental Science 5 (2012) 7869-7871.

[49] I. Vincent, D. Bessarabov, Low cost hydrogen production by anion exchange membrane electrolysis: A review, Renewable and Sustainable Energy Reviews 81 (2018) 1690-1704.

[50] L. An, T. S. Zhao, Z. H. Chai, P. Tan, L. Zeng, Mathematical modeling of an anion-exchange membrane water electrolyzer for hydrogen production, International Journal of Hydrogen Energy 39 (2014) 19869-19876.

[51] C. C. Pavel, F. Cecconi, C. Emiliani, S. Santiccioli, A. Scaffidi, S. Catanorchi, M. Comotti, Highly efficient platinum group metal free based membrane-electrode assembly for anion exchange membrane water electrolysis, Angewandte Chemie International Edition 53 (2014) 1378-1381.

[52] X. Tang, L. Xiao, C. Yang, J. Lu, L. Zhuang, Noble fabrication of Ni-Mo cathode for alkaline water electrolysis and alkaline polymer electrolyte water electrolysis, International Journal of Hydrogen Energy 39 (2014) 30553060.

[53] Y. Leng, G. Chen, A. J. Mendoza, T. B. Tighe, M. A. Hickner, C.-Y. Wang, Solid-state water electrolysis with an alkaline membrane, Journal of the American Chemical Society 134 (2012) 9054-9057.

[54] M. Faraj, M. Boccia, H. Miller, F. Martini, S. Borsacchi, M. Geppi, A. Pucci, New LDPE based anion-exchange membranes for alkaline solid 
polymeric electrolyte water electrolysis, International Journal of Hydrogen Energy 37 (2012) 14992-15002.

[55] H. Ito, N. Kawaguchi, S. Someya, T. Munakata, Pressurized operation of anion exchange membrane water electrolysis, Electrochimica Acta 297 (2019) 188-196.

[56] J. Parrondo, C. G. Arges, M. Niedzwiecki, E. B. Anderson, K. E. Ayersb, V. Ramani, Degradation of anion exchange membranes used for hydrogen production by ultrapure water electrolysis, Royal Society of Chemistry Advances 4 (2014) 9875-9879.

[57] J. R. Varcoe, R. C. T. Slade, Prospects for alkaline anionexchange membranes in low temperature fuel cells, Fuel Cells 5 (2005) 187-200.

[58] B. Bauer, F. Effenberger, H. Strathmann, Anion-exchange with improved alkaline stability, Desalination 79 (1990) 125-144.

[59] A. Buttler, H. Spliethoff, Current status of water electrolysis for energy storage, grid balancing and sector coupling via power-to-gas and power-toliquids: A review, Renewable and Sustainable Energy Reviews 82 (2018) 2440-2454.

[60] K. A. Lewinski, D. van der Vliet, S. M. Luopa, NSTF advances for PEM electrolysis - the effect of alloying on activity of NSTF electrolyzer catalysts and performance of NSTF based PEM electrolyzers, ECS Transactions 69 (2015) 893-917. 
[61] S. Grigoriev, V. Porembskiy, S. Korobtsev, V. Fateev, F. Auprêtre, P. Millet, High-pressure PEM water electrolysis and corresponding safety issues, International Journal of Hydrogen Energy 36 (2011) 2721-2728.

[62] A. S. Gago, J. Bürkle, P. Lettenmeier, T. Morawietz, M. Handl, R. Hiesgen, F. Burggraf, P. A. V. Beltran, K. A. Friedrich, Degradation of Proton Exchange Membrane (PEM) electrolysis: The influence of current density, ECS Transactions 86 (2018) 695-700.

[63] A. S. Gago, P. Lettenmeier, S. Stiber, A. S. Ansar, L. Wang, K. A. Friedrich, Cost-effective PEM electrolysis: The quest to achieve superior efficiencies with reduced investment, ECS Transactions 85 (2018) 3-13.

[64] S. Y. Gómez, D. Hotza, Current developments in reversible solid oxide fuel cells, Renewable and Sustainable Energy Reviews 61 (2016) 155-174.

[65] S. P. Badwal, S. Giddey, C. Munnings, Emerging technologies, markets and commercialization of solid-electrolytic hydrogen production, Wiley Interdisciplinary Reviews: Energy and Environment 7 (2018) 286-304.

[66] M. Felgenhauer, T. Hamacher, State-of-the-art of commercial electrolyzers and on-site hydrogen generation for logistic vehicles in South Carolina, International Journal of Hydrogen Energy 40 (2015) 2084-2090.

[67] M. Schalenbach, A. R. Zeradjanin, O. Kasian, S. Cherevko, K. J. Mayrhofer, A perspective on low-temperature water electrolysis challenges in alkaline and acidic technology, International Journal of Electrochemical Science 13 (2018) 1173-1226. 
[68] J. Divisek, P. Malinowski, J. Mergel, H. Schmitz, Improved construction of an electrolytic cell for advanced alkaline water electrolysis, International Journal of Hydrogen Energy 10 (1985) 383-388.

[69] M. Schalenbach, W. Lueke, D. Stolten, Hydrogen diffusivity and electrolyte permeability of the Zirfon PERL separator for alkaline water electrolysis, Journal of Electrochemical Society 163 (2016) 1480-1488.

[70] A. Li, Y. Sun, T. Yao, H. Han, Earth-abundant transition-metal-based electrocatalysts for water electrolysis to produce renewable hydrogen, Chemistry European Journal 24 (2018) 18334-18355.

[71] J. Tian, Q. Liu, A. M. Asiri, X. Sun, Self-supported nanoporous cobalt phosphide nanowire arrays: An efficient 3D hydrogen-evolving cathode over the wide range of $\mathrm{pH}$ 014, Journal of the American Chemical Society 136 (2014) 7857-7950.

[72] S. Meyer, A. V. Nikiforov, I. M. Petrushina, K. Kohler, E. Christensen, J. O. Jensen, N. J. Bjerrum, Transition metal carbides (WC, Mo2C, TaC, NbC) as potential electrocatalysts for the hydrogen evolution reaction (HER) at medium temperatures, International Journal of Hydrogen Energy 40 (2015) 2905-2911.

[73] Q. Feng, G. Liu, B. Wei, Z. Zhang, H. Li, H. Wang, A review of proton exchange membrane water electrolysis on degradation mechanisms and mitigation strategies, Journal of Power Sources 366 (2017) 33-55.

[74] S. Sun, Z. Shao, H. Yu, G. Li, B. Yi, Investigations on degradation of the 
long-term proton exchange membrane water electrolysis stack, Journal of Power Sources 267 (2014) 515-520.

[75] A. Kusoglu, A. M. Karlsson, M. H. Santare, S. Cleghorn, W. B. Johnson, Mechanical behavior of fuel cell membranes under humidity cycles and effect of swelling anisotropy on the fatigue stresses, Journal of Power Sources 170 (2007) 345-358.

[76] M. Chandesris, V. Médeau, N. Guillet, S. Chelghoum, D. Thoby, F. FoudaOnana, Membrane degradation in PEM water electrolyzer: Numerical modeling and experimental evidence of the influence of temperature and current density, International Journal of Hydrogen Energy 40 (2015) 13531366.

[77] C. Rakousky, U. Reimer, K. Wippermann, M. Carmo, W. Lueke, D. Stolten, An analysis of degradation phenomena in polymer electrolyte membrane water electrolysis, Journal of Power Sources 326 (2016) 120-128.

[78] H. Vandenborre, R. Leysen, L. H. Baetsle, Alkaline inorganic-membraneelectrolyte (IME) water electrolysis, International Journal of Hydrogen Energy 5 (1980) 165-171.

[79] P. Vermeiren, W. Adriansens, J. P. Moreels, R. Leysen, Evaluation of the Zirfon separator for use in alkaline water electrolysis and $\mathrm{Ni}-\mathrm{H}_{2}$ batteries, International Journal of Hydrogen Energy 23 (1998) 321-324.

[80] K. Rajeshwar, R. McConnell, S. Licht, Solar Hydrogen Generation. Toward a renewable energy future, Springer-Verlag, 2008. 
[81] T. Ogawa, M. Takeuchi, Y. Kajikawa, Analysis of trends and emerging technologies in water electrolysis research based on a computational method: A comparison with fuel cell research, Sustainability 10 (2018) $478-501$.

[82] K. Onda, T. Kyakuno, K. Hattori, K. Ito, Prediction of production power for high-pressure hydrogen by high-pressure water electrolysis, Journal of Power Sources 132 (2004) 64-70.

[83] C. Ziems, D. Tannert, H. J. Krautz, Project presentation: design and installation of advanced high pressure alkaline electrolyzer-prototypes, Energy Procedia 29 (2012) 744-753.

[84] A. Roy, S. Watson, D. Infield, Comparison of electrical energy efficiency of atmospheric and high-pressure electrolysers, International Journal of Hydrogen Energy 31 (2006) 1964-1979.

[85] F. Allebrod, C. Chatzichristodoulou, M. B. Mogensen, Alkaline electrolysis cell at high temperature and pressure of $250^{\circ} \mathrm{C}$ and $42 \mathrm{bar}$, Journal of Power Sources 229 (2013) 22-31.

[86] J. Ganley, High temperature and pressure alkaline electrolysis, International Journal of Hydrogen Energy 34 (2009) 3604-3611.

[87] O. Ulleberg, Modeling of advanced alkaline electrolyzers: a system simulation approach, International Journal of Hydrogen Energy 28 (2003) 21-33.

[88] H. Barthels, W. Brocke, K. Bonhoff, H. Groehn, G. Heuts, M. Lennartz, H. Mai, J. Mergel, L. Schmid, P. Ritzenhoff, Phoebus-Jülich: an autonom- 
ous energy supply system comprising photovoltaics, electrolytic hydrogen, fuel cell, International Journal of Hydrogen Energy 23 (1998) 295-301.

[89] A. Ursúa, P. Sanchis, Static-dynamic modelling of the electrical behaviour of a commercial advanced alkaline water electrolyser, International Journal of Hydrogen Energy 37 (2012) 18598-18614.

[90] A. Roy, Dynamic and transient modelling of electrolysers powered by renewable energy sources and cost analysis of electrolytic hydrogen, Ph.D. thesis, Loughborough University (2006).

[91] K. Zouhri, S. Lee, Evaluation and optimization of the alkaline water electrolysis ohmic polarization: Exergy study, International Journal of Hydrogen Energy 41 (2016) 7253-7263.

[92] B. Choi, D. Panthi, M. Nakoji, T. Kabutomori, K. Tsutsumi, A. Tsutsumi, A novel water-splitting electrochemical cycle for hydrogen production using an intermediate electrode, Chemical Engineering Science 157 (2017) 200208.

[93] P. Charvin, S. Abanades, G. Flamant, F. Lemort, Two-step water splitting thermochemical cycle based on iron oxide redox pair for solar hydrogen production, Energy 32 (2007) 1124-1133.

[94] A. Steinfeld, Solar hydrogen production via a two-step water splitting thermochemical cycle based on zn/zno redox reactions, International Journal of Hydrogen Energy 27 (2005) 611-619. 
[95] K. Mazloomi, N. Sulaiman, S. A. Ahmad, N. Yunus, Analysis of the frequency response of a water electrolysis cell, International Journal of Electrochemical Science 8 (2013) 3731-3739.

[96] N. Shimizu, S. Hotta, T. Sekiya, O. Oda, A novel method of hydrogen generation by water electrolysis using an ultra-short-pulse power supply, Journal of applied electrochemistry 36 (2006) 419-423.

[97] M. Vanags, J. Kleperis, G. Bajars, Water electrolysis with inductive voltage pulses, in: Electrolysis, InTech, 2012.

[98] A. H. Shaaban, Pulsed DC and anode depolarization in water electrolysis for hydrogen generation, Tech. rep., Air Force Civil Engineering Support Agency (1994).

[99] S. Mazloomi, N. Sulaiman, Influencing factors of water electrolysis electrical efficiency, Renewable and Sustainable Energy Reviews 16 (2012) $4257-4263$.

[100] Z. Dobó, A. B. Palotás, Impact of the voltage fluctuation of the power supply on the efficiency of alkaline water electrolysis, International Journal of Hydrogen Energy 41 (2016) 11849-11856.

[101] Z. Dobó, A. B. Palotás, Impact of the current fluctuation on the efficiency of alkaline water electrolysis, International Journal of Hydrogen Energy 42 (2017) 5649-5656.

[102] A. Mauer, D. Kirk, T. Steven, The role of iron in the prevention of nickel electrode deactivation in alkaline electrolysis, Electrochimica Acta 52 (2007) 3505-3509. 
[103] R. M. Abouatallah, D. W. Kirk, S. J. Thorpe, J. W. Graydon, Reactivation of nickel cathodes by dissolved vanadium species during hydrogen evolution in alkaline media, Electrochimica Acta 47 (2001) 613-621.

[104] K. Zeng, D. Zhang, Recent progress in alkaline water electrolysis for hydrogen production and applications, Progress in Energy and Combustion Science 36 (2010) 307-326.

[105] R. Singh, D. Mishra, Anindita, A. Sinha, A. Singh, Novel electrocatalysts for generating oxygen from alkaline water electrolysis, Electrochemistry Communications 9 (2007) 1369-1373.

[106] M. El-Deab, M. Awad, A. Mohammad, T. Ohsaka, Enhanced water electrolysis: electrocatalytic generation of oxygen gas at manganese oxide nanorods modified electrodes, Electrochemistry Communications 9 (2007) 2082-2087.

[107] M. Hamdani, M. Pereira, J. Douch, A. Addi, Y. Berghoute, M. Mendonca, Physicochemical and electrocatalytic properties of $\mathrm{LiCo}_{3} \mathrm{O}_{4}$ anodes prepared by chemical spray pyrolysis for application in alkaline water electrolysis, Electrochimica Acta 49 (2004) 1555-1563.

[108] H. Wendt, H. Hofmann, V. Plzak, Materials research and development of electrocatalysts for alkaline water electrolysis, Materials Chemistry and Physics 22 (1989) 27-49.

[109] F. Crnkovic, S. Machado, L. Avaca, Electrochemical and morphological studies of electrodeposited NiFeMoZn alloys tailored for water electrolysis, International Journal of Hydrogen Energy 29 (2004) 249-254. 
[110] Q. Han, K. Liu, J. Chen, X. Wei, Hydrogen evolution reaction on amorphous NiSCo alloy in alkaline medium, International Journal of Hydrogen Energy 28 (2003) 1345-1352.

[111] G. Sheela, M. Pushpavanam, S. Pushpavanam, Hydrogen evolution reaction on amorphous NiSCo alloy in alkaline medium, International Journal of Hydrogen Energy 27 (2002) 627-633.

[112] W. Hu, Electrocatalytic properties of new electrocatalysts for hydrogen evolution in alkaline water electrolysis, International Journal of Hydrogen Energy 25 (2000) 111-118.

[113] W. Hu, J. Lee, Electrocatalytic properties of $\mathrm{Ti}_{2} \mathrm{Ni} / \mathrm{NiMo}$ composite electrodes for hydrogen evolution reaction, International Journal of Hydrogen Energy 23 (1998) 253-257.

[114] P. Los, A. Rami, A. Lasia, Hydrogen evolution reaction on NiAl electrodes, Journal of Applied Electrochemistry 23 (1993) 135-140.

[115] I. Raj, Nickel-based, binary-composite electrocatalysts for the cathodes in the energy-efficient industrial-production of hydrogen from alkaline-water electrolytic cells, Journal of Materials Science 28 (1993) 4375-4382.

[116] D. Abbott, Keeping the energy debate clean: How do we supply the world's energy needs?, Proceedings of the IEEE 98 (2009) 42-66.

[117] M. J. Lavorante, J. I. Franco, Performance of stainless steel 316L electrodes with modified surface to be use in alkaline water electrolyzers, International Journal of Hydrogen Energy 41 (2016) 9731-9737. 
[118] A. Cruden, D. Infield, M. Kiaee, T. G. Douglas, A. Roy, Development of new materials for alkaline electrolysers and investigation of the potential electrolysis impact on the electrical grid, Renewable Energy 49 (2013) $53-$ 57.

[119] F. M. Sapountzi, J. M. Gracia, C. K.-J. Weststrate, H. O. Fredriksson, J. H. Niemantsverdriet, Electrocatalysts for the generation of hydrogen, oxygen and synthesis gas, Progress in Energy and Combustion Science 58 (2017) $1-35$.

[120] B. Pierozynski, T. Mikolajczyk, K. IM., Hydrogen evolution at catalytically modified nickel foam in alkaline solution, Journal of Power Sources 271 (2014) 231-238.

[121] S. Shibli, G. Harikrishnan, V. Anupama, K. Chinchu, M. BN, Development of nano $\mathrm{NiO}$ incorporated nickel-phosphorus coatings for electrocatalytic applications, Surface and Coatings Technology 262 (2015) 48-55.

[122] M. A. McArthur, S. Jorge, L. Coulombe, S. Omanovic, Synthesis and characterization of 3D Ni nanoparticle/carbon nanotube cathodes for hydrogen evolution in alkaline electrolyte, Journal of Power Sources 266 (2014) 365373.

[123] L. Zhang, K. Xiong, S. Chen, L. Li, Z. D. Deng, Zihua Wei, In situ growth of ruthenium oxide-nickel oxide nanorod arrays on nickel foam as a binderfree integrated cathode for hydrogen evolution, Journal of Power Sources 274 (2015) 114-120. 
[124] X. Ji, R. Zhang, X. Shi, A. M. Asiri, B. Zheng, X. Sun, Fabrication of hierarchical CoP nanosheet microwire array via space-confined phosphidation toward high-efficiency water oxidation electrocatalysis under alkaline conditions, Nanoscale 10 (2018) 7941-7945.

[125] Y. Ji, L. Yang, X. Ren, G. Cui, X. Xiong, X. Sun, Full water splitting electrocatalyzed by NiWO4 nanowire array, ACS Publications 6 (2018) 9555-9559.

[126] Z. Wang, X. Ren, L. Wang, G. Cui, H. Wang, X. Sun, A hierarchical CoTe 2-MnTe 2 hybrid nanowire array enables high activity for oxygen evolution reactions, Chemical Communications 54 (2018) 10993-10996.

[127] J. Zhao, X. Li, G. Cui, X. Sun, Highly-active oxygen evolution electrocatalyzed by an Fe-doped NiCr 2 o 4 nanoparticle film, Chemical Communications 54 (2018) 5462-5465.

[128] Y. Ji, L. Yang, X. Ren, G. Cui, X. Xiong, X. Sun, Nanoporous CoP3 nanowire array: acid etching preparation and application as a highly active electrocatalyst for the hydrogen evolution reaction in alkaline solution, ACS Sustainable Chemistry \& Engineering 6 (2018) 11186-11189.

[129] T. Liu, L. Xie, J. Yang, R. Kong, G. Du, A. M. Asiri, X. Sun, L. Chen, Selfstanding CoP nanosheets array: A three-dimensional bifunctional catalyst electrode for overall water splitting in both neutral and alkaline media, ChemElectroChem 4 (2017) 1840-1845.

[130] Z. Wang, X. Ren, Y. Luo, L. Wang, G. Cui, F. Xie, H. Wang, Y. Xie, X. Sun, Ultrafine platinum-cobalt alloy decorated cobalt nanowire array with su- 
perb activity toward alkaline hydrogen evolution, Nanoscale 10 (2018) 12302-12307.

[131] P. Haug, M. Koj, T. Turek, Influence of process conditions on gas purity in alkaline water electrolysis, International Journal of Hydrogen Energy 42 (15) (2017) 9406-9418. 